\title{
On Fennoscandian polypores 5. Phellinus pomaceus
}

\author{
TUOMO NIEMELÄ
}

\begin{abstract}
NIEMELÄ, T. 1977: On Fennoscandian polypores 5. Phellinus pomaceus. - Karstenia 17: $77-86$.

The anatomy, distribution, pathology and cultural characters of Phellinus pomaceus (Pers. ex S.F. Gray) Maire are described on the basis of ca. 470 North European specimens. The main anatomical features separating the species from the $P$. igniarius complex are the subparallel dissepimental hyphae and thin-walled skeletals in the context. $P$. pomaceus is fairly common in hemiboreal and temperate southern Fennoscandia, but does not extend farther north. In this region, it occurs almost exclusively on Prunus species, mainly $P$. domestica L., $P$. cerasus L. and $P$. spinosa L., but it has been reported only twice from $P$. padus L., the commonest Prunus species in Fennoscandia. The cultural characters and anatomy show that $P$. pomaceus is taxonomically homogeneous in $\mathrm{N}$ Europe, except perhaps for a form growing on Crataegus.

A lectotype is selected for $P$. pomaceus, and the taxonomic position of some closely related taxa (Polyporus corni Velen., Fomes pomaceus f. crataegi Baxter, Fomitiporia prunicola Murr.) is shortly discussed.
\end{abstract}

Tuomo Niemelä, Department of Botany, University of Helsinki, Unioninkatu 44, SF-00170 Helsinki 17, Finland

Phellinus pomaceus (Pers. ex S.F. Gray) Maire is closely related to the $P$. igniarius complex (Niemelä 1972, 1974, 1975), being especially similar in its morphology. However, in the microscope and in culture it is clearly separated from the species of that group, and its specific status is at present almost universally acknowledged. This applies to the typical pileate specimens growing on plum, cherry, and other species of the genus Prunus s. lat.

The picture is not, however, so simple everywhere. In Central and South Europe, closely related taxa occurring on hosts other than Prunus need a detailed comparison with the basic material, and in North America, certain effused species of Phellinus show a very close affinity to $P$. pomaceus. In this paper a detailed description is given of the North European $P$. pomaceus.

\section{Materials and methods}

The description is based on ca. 470 Fennoscandian specimens. The procedures followed in measuring the structural details, and collecting the other data were the same as in my previous studies on the genus. The microscopical measurements were made in Melzer's reagent.
Material was received from the following herbaria: BG, C, GB, H, HFR, HPP, KUO, L, LE, MICH, NFRI (Norwegian Forest Research Institute, Ås), NPPI (Norwegian Plant Protection Institute, As), O, OULU, PRC, PRM, S, TRH, TUR and UPS. In addition, collections were studied from the private herbaria of Dr. John Eriksson (Göteborg, Sweden), Dr. Ingvar Nordin (Göteborg), Dr. Åke Strid (Stockholm) and myself.

The cultural strains are maintained in the author's collection in $\mathrm{H}$, and the corresponding herbarium specimens are deposited in $\mathrm{H}$ and HFR.

\section{Phellinus pomaceus}

Phellinus pomaceus (Pers. ex S.F. Gray) Maire, Mus. Barcin. Sci. Nat. Op. 15 (Fungi Catal.): 37. 1933. Type: no original designation, lectotype: 'Polyporus pomaceus. Boletus. Gallia. Hb. Pers. Ad truncos praesertim Prunorum et Cerasorum.' (Herb. Persoon, L, no. 910.263-397, selected here).

[Boletus pomaceus Persoon, Observ. Mycol. 2: 5. 1799.] - Boletus pomaceus Pers. ex S.F. Gray, Nat. Arrangem. British Plants I: 642. 1821. - Fomes pomaceus (Pers. ex S.F. Gray) Lloyd, Mycol. Writ. 2: 8. 1908. Ochroporus pomaceus (Pers. ex S.F. Gray) Donk, Mededeelingen Bot. Mus. Herb. Rijksuniversiteit Utrecht 9: 250, 1933.

For synonyms, see Niemelä (1975: 120) and Ryvarden \& Calonge (1976). 

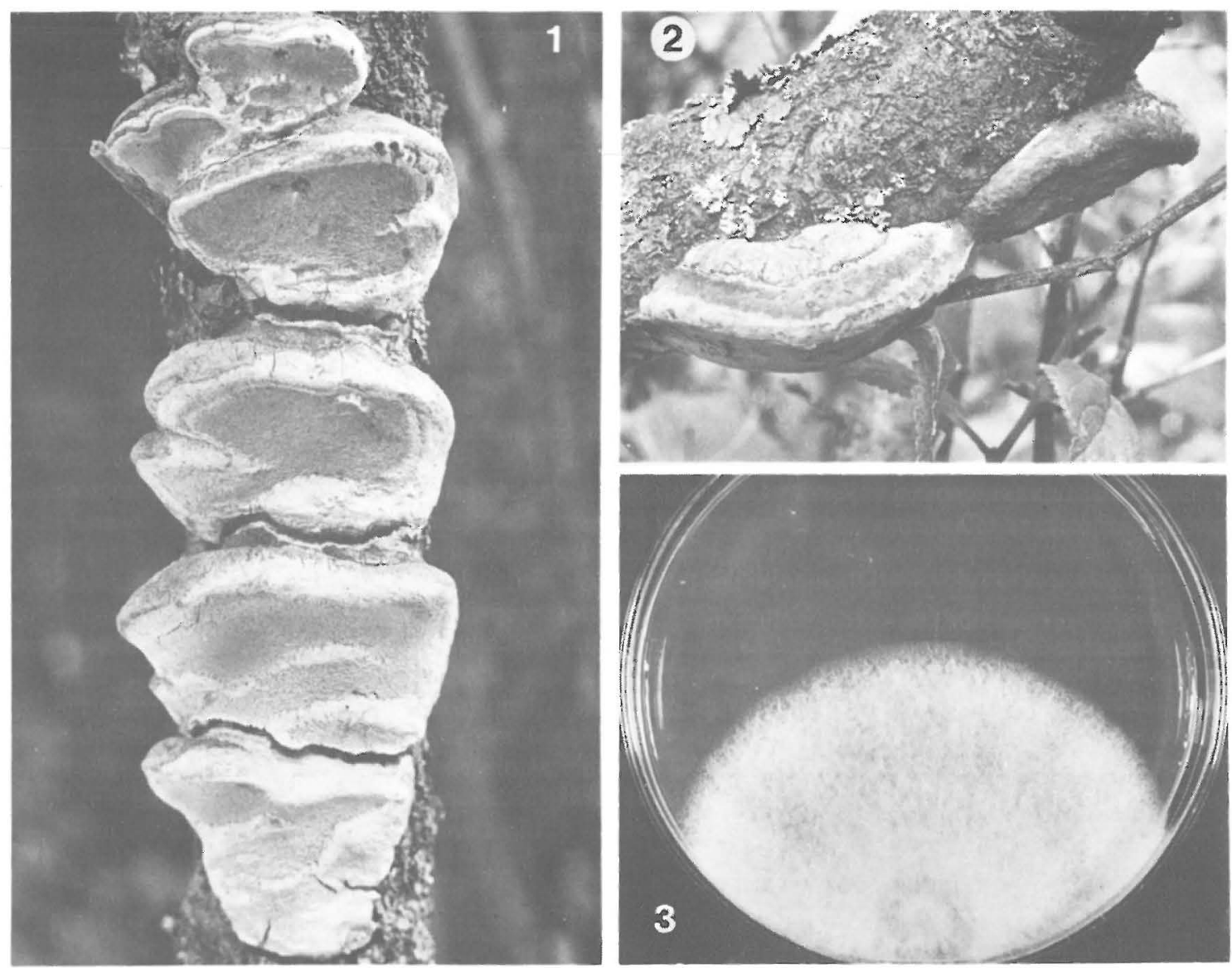

Figs. 1-3. Phellinus pomaceus. -1 : Imbricate fruit bodies on the vertical trunk of Prunus cerasus, $\times 0.5$ (specimen Aalto $537, \mathrm{H}),-2$ : Solitary fruit bodies on $P$. domestica, $\times 0.7$ (Niemelä 446, H). -3 : Culture, grown on malt agar, at $24^{\circ} \mathrm{C}$, for two weeks. Petri dish diameter $9 \mathrm{~cm}$ (Åkerman 236, HFR). Photo Tuomo Niemelä.

Perennial, single, or often in groups and confluent (Figs. 1-2). Fruit body flat and widely attached to substrate, pileate or more often thickly effused-reflexed, young specimens seldom thinly resupinate, more often nodular. Pileate part projecting $1-4.5 \mathrm{~cm}$ from substrate, $1-4 \mathrm{~cm}$ thick at base and $2.5-7 \mathrm{~cm}$ wide, old specimens sometimes larger. Mature effused or effused-reflexed specimens grown on under sides of branches ellipsoid when viewed from below, $3-15 \times 2-6 \mathrm{~cm}, 8-20 \mathrm{~mm}$ thick.

Surface various shades of light grey, with tint of sepia or ochre towards margin, cinnamon when growing actively, lustreless, minutely rough, growth zones wide, flat and irregular, or indistinct. Old specimens with dark grey, irregularly rimose upper surface. Surface glabrous and compact, but with no distinct crust, except in oldest rimose fruit bodies.
Edge roundish, or often somewhat acute, sterile margin (best seen in effused part) $1-3 \mathrm{~mm}$ wide, cinnamon.

Hymenial surface even, oblique, concave in profile, golden brown - greyish brown - light grey, according to state of growth, with slight glitter when growing actively, such parts turning rust brown if bruised when fresh. Pores regular, (4-) 5-6 (-7) per $\mathrm{mm}$, round or ellipsoid, sometimes elongated or angular if tightly packed, $0.11-0.18(-0.29) \times$ $0.09-0.16 \mathrm{~mm}$ in inner diameter (measured from transverse section), most pores $0.10-0.18 \mathrm{~mm}$ in diameter, dissepiments $0.02-0.10 \mathrm{~mm}$ thick. Dissepiment edges matt in weathered specimens, velvety when growing actively, rounded.

Context in section relatively thick at base, $3-16$ (-25) $\mathrm{mm}$ thick, yellowish brown, lustrous especially if split when dry; subiculum in effused speci- 

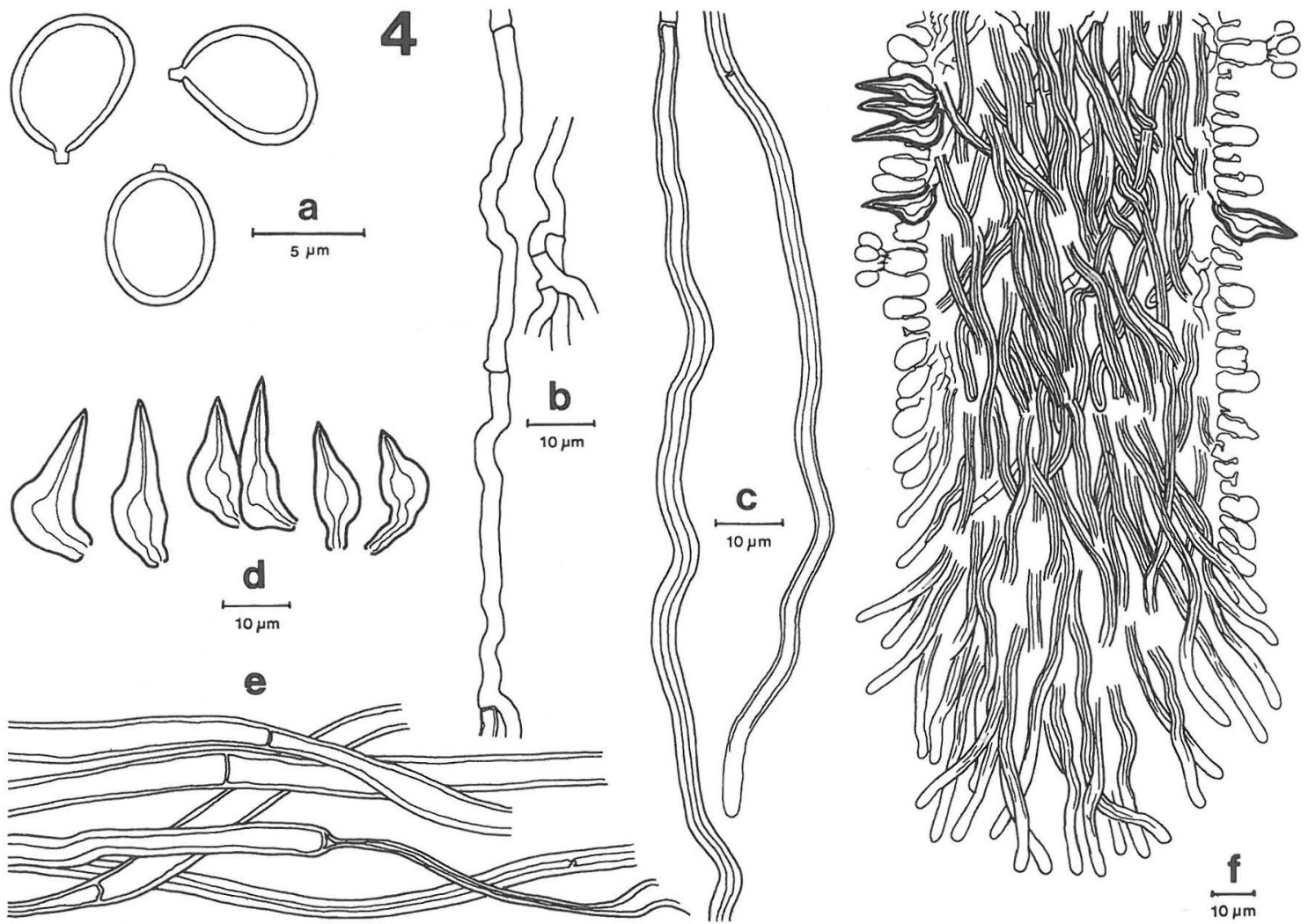

Fig. 4. Anatomical details of Phellinus pomaceus: a) spores, b) generative hyphae from dissepiment, c) skeletal hypha from dissepiment, d) hymenial setae, e) skeletal hyphae from context, f) dissepiment edge in vertical section (specimen 21.IV.1973 Tuomikoski, H).

mens mostly very thin, $1 \mathrm{~mm}$ or less. Oldest context near substrate lighter brown because of white radial stripes, no core (in few cases very rudimentary core present). Tube layer (trama) in section light brown, in older specimens with fairly distinct annual layers 3-5 $\mathrm{mm}$ thick, mycelium filling old tubes white.

Fresh fruit body easily cut; dried specimens woody, lighter than e.g. those of $P$. igniarius and more easily split with a knife.

Spores (5.0-) 5.8-6.4 (-7.0) $\times(4.0-)$ $4.6-5.0(-5.4) \mu \mathrm{m}$, single or loosely agglutinated in very fertile specimens, ellipsoid, with somewhat applanated supra-apicular region (Fig. 4). Wall thin, $0.3-0.5 \mu \mathrm{m}$, smooth, hyaline, nonamyloid, indextrinoid, weakly cyanophilous. Apiculus small, $0.4 \times$ $0.4 \mu \mathrm{m}$. In dry material spores often collapsed and angular.

Basidia thickly clavate, $10-13 \times 6-7.5 \mu \mathrm{m}$, with four sterigmata $3 \mu \mathrm{m}$ long; basidioles $9-12 \times$ 5.5-6.5 $\mu \mathrm{m}$; collapsed hymenium visible as honey- comb structure with cells $4-5.5 \mu \mathrm{m}$ in diam., and with walls $0.8-1.6 \mu \mathrm{m}$ thick and $4-5 \mu \mathrm{m}$ high. Hymenial setae (12.0-) $15.5-19.5(-29.0) \times$ (5.5-) 6.3-7.4 (-8.5) $\mu \mathrm{m}$, length/width index $2.2-2.6(-2.9)$. Setae sometimes few but always present, reddish to yellowish brown, thick-walled, subulate, regular with stout apex and sometimes with heel.

Subhymenium indistinct. Hyphal system dimitic. Hyphae nonamyloid, indextrinoid, non-cyanophilous (except hyphal tips), skeletals darkening in $\mathrm{KOH}$.

Hyphae in hymenial trama subparallel. Generative hyphae $2-3 \mu \mathrm{m}$, with $0.2-0.4 \mu \mathrm{m}$ thick hyaline walls, branched and simple-septate. Skeletal hyphae 2.5-3.7 (-4.0) $\mu \mathrm{m}$ in diam., unbranched, seldom simple-septate, with yellowish brown, 0.9-1.5 $\mu \mathrm{m}$ thick walls, or with thinner yellow walls in proximal parts.

Context hyphae with distinct radial orientation, though not strictly parallel. Generative hyphae up to 
$3.5 \mu \mathrm{m}$ thick, colourless, few. Skeletal hyphae in context (3.0-) 4.0-6.1 $\mu \mathrm{m}$ in diam.; hyphal walls $0.5-1.0(-1.3) \mu \mathrm{m}$, i.e. thin in relation to lumina; skeletals often collapsing and flattening, yellowish brown also when thin-walled, unbranched but often and distinctly septate.

In Fennoscandia a southern species, locally common in the hemiboreal and temperate parts (oak zone). On dying and dead standing trunks of Prunus species, mostly $P$. domestica and $P$. cerasus in orchards.

\section{Taxonomy}

$P$. pomaceus is genetically rather uniform in northern Europe, as is evident from the simple host spectrum, and lack of marked variation in the cultural characters. It can be separated from the species of the $P$. igniarius complex by its yellowish brown, lustrous context, subparallel skeletal hyphae in the dissepimental trama, and the wide, thinwalled, collapsing contextual skeletals.

I have studied two specimens collected from Crataegus in Europe. One, from Germany, Munich (1889 Schnabl 981, H), is microscopically and macroscopically similar to $P$. pomaceus growing on Prunus.

The other collection (Sweden, Öland, Crataegus sp., 1964 Strid 410, S) differs from the typical $P$. pomaceus in having very narrow setae $(17-25 \times$ 4.5-6.5 $\mu \mathrm{m}$, index 3.5; these measurements not included in the description), but resembles it in the spore and pore measurements, effused-reflexed fruit bodies and other characters. This specimen accords rather well with the North American taxon which Baxter (1925, 1934) calls Fomes pomaceus f. crataegi Baxter.

No type was found for $F$. pomaceus f. crataegi in the Baxter herbarium (MICH), and the North Carolina specimen mentioned in the original description of the form is also missing (Dr. Robert L. Shaffer, in litt.). The other material determined as f. crataegi by Baxter consists of effused-reflexed fruit bodies. The pores are rounded, 5-6 (-7) per mm, i.e., they correspond to those of $P$. pomaceus. The spores are (4.2-) 4.5-5.0 (-5.3) × (3.5-) 3.8$4.1(-4.7) \mu \mathrm{m}$; the setae (13.5-) $15.1-18.6$ $(-22.0) \mu \mathrm{m}$, their index (2.6-) 3.0-3.3, i.e., they are narrower than in the European $P$. pomaceus. The skeletal hyphae in the dissepimental trama are more parallel than in the European taxon, and those in the context are thinner, with thicker walls, hardly differing from those in the dissepiments. So this form does differ in certain respects, though some of the differences, e.g. those in the spore measurements, may not be important; the $\mathrm{N}$ American material of $P$. pomaceus also has somewhat smaller spores than the European one (Overholts 1953).

No decisions should be made about the identity of the form on Crataegus before more European material is available. Baxter's results suggest that cultural studies might be especially useful in deciding whether the Crataegus form is a separate taxon or not.

Other unsolved problems are those posed by the resupinate Phellinus pomaceus var. prunastri (Pers. ex S.F. Gray) Pat., which should be compared with an American species, Fomitiporia prunicola Murr., and the South European P. pomaceus var. oleae Hart. ex Erikss. These do not occur in North Europe, and are not dealt with further there. The taxonomy of this species group is much more complicated in North America than in Europe, and can hardly be solved without cultural studies.

From time to time the name Polyporus fulvus Scop. ex Fr. has been applied to the present species. The use of this name is discouraged because, as pointed out by Donk $(1971,1974)$, it is a nomen ambiguum, and was revalidated later (Fries 18361838) than Boletus pomaceus Pers. ex S.F. Gray (1821).

The lectotype selected from the Persoon collection of the Rijksherbarium, Leiden, consists of two effused-reflexed fruit bodies with a grey upper surface, cinnamon pore layer, and a tube layer that is characteristically yellowish brown in section. The specimen is a good representative of $P$. pomaceus as described here.

\section{Distribution}

\section{Fennoscandian specimens examined:}

\section{Norway:}

Östfold. Aremark (1 specimen). Borge (1). Hvaler (2). Idd (2). Kråkeröy (1). Rygge (1). Skjeberg (2). Tune (5). Akershus og Oslo. Asker (5). Baerum (1). Oslo (12). Oppland. Östre Toten (2). - Buskerud. Drammen (2). Hurum (2). Lier (11). Övre Eiker (1). Röyken (1). Skollenborg (1). - Vestfold. Borre (3). Larvik (5). Nötteröy (3). Sandar (2). Sande (1). Sem (1). Stokke (1). Svelvik (1). Tjölling (3). - Telemark. Bamble (1). Gjerpen (1). Nissedal (1). Nome (2). Porsgrunn (1). Sauherad (1). Skien (6). - Aust-Agder. Fjaere (2). Gjerstad (1). Grimstad (1). Landvik (2). Moland (3). Oyestad (1). Risör (5). - VestAgder. Greipstad (1). Kristiansand (4). Lyngdal (1). Mandal (1). Sögne (1). - Hordaland. Ullensvang (3).

\section{Sweden:}

Gotland. Burs (1). Fröjel (1). Hejdeby (1). Klinte (1). Lummelunda (1). Öja (1). Roma (1). Sjonhem (2). Sproge 
(1). Tofta (1). Visby (2). - Öland. Borgholm (2). Torslunda (1). - Skåne. Alstad (1). Båstad (2). Lund (1). Revinge (1). Torekov (3). - Blekinge. Åryd (2). Karlskrona (2). - Småland. Ålem (1). Femsjö (6). - Halland. Fjärås (2). Östra Karup (2). Släp (1). Vallda (2). - Bohuslän. Lane-Ryr (2). Lycke (3). Valla (5). - Dalsland. Ånimskog (3). Ekholmen (2). Gunnarsnäs (1). Holm (1). - Västergötland. Alingsås (3). Floby (3). Göterborg (44). Gryt (1). Hemsjö (6). Kullings-Skövde (1). Leksberg (1). Lerum (1). Marum (1). Medelplana (2). Mölndal (19). Säve (2). Södra Kedum (2). Sörby (1). Töreboda (4). Ullene (1). Vänersborg (1). Västra Frölunda (3). Vilske-Kleva (1). Östergötland. Björsäter (1). Gryt (6). Linköping (2). Värmland. Sunne (2). - Närke. Kvistbro (1). Örebro (1). - Södermanland. Aspö (1). Björkvik (1). Nacka (3). Nyköping (13). Nynäshamn (1). Stockholm (6). Trångsund (1). Tumba (1). - Uppland. Alsike (1). Djurö (1). Ekerö (3). Enköping-Näs (3). Estuna (1). Färentuna (1). Gryta (6). Hacksta (6). Hilleshög (1). Kulla (1). Läby (1). Lagga (1). Lena (1). Litslena (3). Lovö (1). Österlövsta (14). Sigtuna (1). Stockholm (8). Täby (1). Teda (2). Uppsala (20). Vallby (1). Vallentuna (1). Veckholm (3). Vidbo (1). Vrå-Knivsta (1). - Västmanland. Harbo (1). Irsta (2). Kila (3). Lundby (5). Rytterne (4). Sala (2). Västerås (3). Västerås-Barkarö (1). - Gästrikland. Gävle (3).

Finland:

Ahvenanmaa. Finström (1). Jomala (7). - Varsinais-Suomi. Kaarina (4). Karjalohja (5). Karuna (1). Kemiö (1).
Korppoo (3). Lohja (1). Mynämäki (1). Naantali (1). Nauvo (1). Parainen (3). Rymättylä (1). Sammatti (2). Turku (3). Vihti (2). - Uusimaa. Helsinki (8). Inkoo (1). Nurmijärvi (1). Porvoo (2). Sipoo (1). Siuntio (1). Tammisaari (3). - Etelä-Karjala. Vehkalahti (1). Virolahti (2).

The northern distribution limit of $P$. pomaceus in Fennoscandia coincides remarkably closely with the northern boundary of the oak zone, or the hemiboreal zone, as outlined by Ahti et al. (1968: 188). This applies especially for south-eastern Norway, Sweden and western Finland; in many places the northernmost finds lie exactly at the boundary of the zone (Fig. 5).

On the western coast of Norway, the species seems to be rare and does not extend to the nortern limit of the hemiboreal zone. It must be pointed out, however, that the zone is very narrow and rather fragmentary there, and in some delimitations it has not been considered to reach so far north. The finds in south-eastern Finland do not represent a significant discrepancy in the distribution picture, as the whole coastal strip along the northern shore of the Gulf of Finland is climatically relatively uniform. In fact, the eastern part and the adjacent

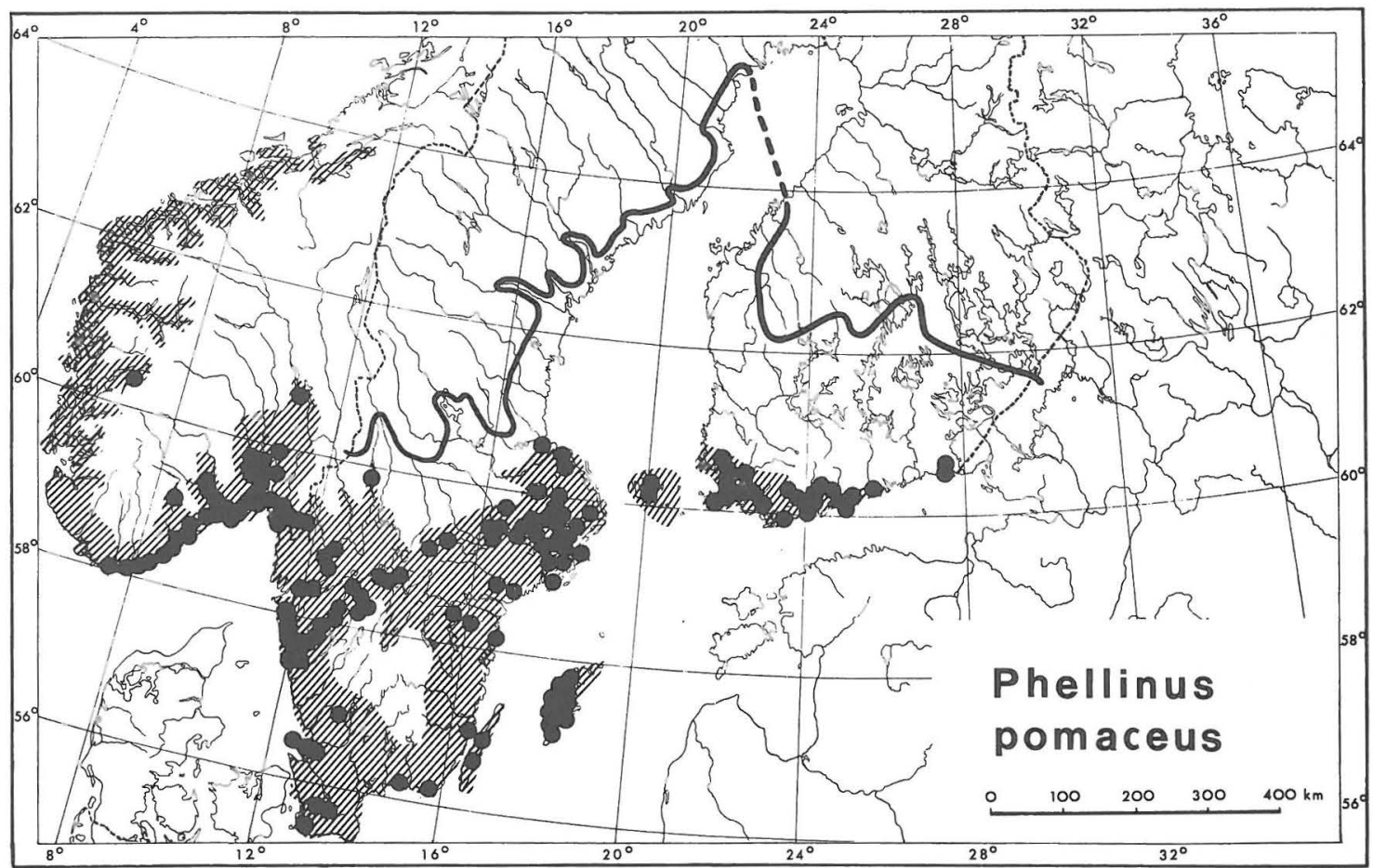

Fig. 5. The distriburion of Phellinus pomaceus in Fennoscandia. The dots represent the specimens examined. The shaded areas are the hemiboreal and temperate parts of Fennoscandia. The black line shows the approximate northern limit of cultivated Prunus domestica and P. cerasus in Sweden and Finland. 
Vyborg region in the U.S.S.R. are often included in the oak zone.

No specimens were received from the southern boreal inland outlier in southern Sweden.

The southern character of the distribution of $P$. pomaceus is remarkable, because its hosts, for instance Prunus domestica, are cultivated much farther north. The exact northern limit for cultivated species of Prunus cannot be easily drawn, as it fluctuates to some extent with long-term climatic changes, and because the northernmost planting trials seldom produce adult fruit trees to serve as potential hosts for $P$. pomaceus. The boundary drawn in Fig. 5 is based mainly on Ullström (1961) for Sweden, and on Palmgren \& Lokonen (1969) and personal communications for Finland, and represents only the approximate northern limit of the occurrence of fully grown fruit trees.

Within its area of distribution in Fennoscandia, $P$. pomaceus is fairly common in old plum and cherry orchards. The local variations in the amounts of herbarium specimens doubtless reflect variations in collecting activity rather than real differences in the occurrence of the species.

North of the distribution limit of $P$. pomaceus, the most important pathogen of plum and cherry is $P$. igniarius var. igniarius.

$P$. pomaceus occurs widely in Europe, and seems to be absent only from Iceland (Hallgrímsson 1966). In western and central Europe, records are known to me from Denmark (Lange 1961), Great Britain (Pegler 1966, Pegler \& Waterson 1968), the Netherlands (Boerema \& Verhoeven 1972), the Federal Republic of Germany (Jahn 1963), the German Democratic Republic (Kreisel 1961), Austria (coll. 1899 Strasser, H), Switzerland (Göpfert 1973), Poland (Domański et al. 1973), Czechoslovakia (Pilát 1936-1942, Balaban \& Kotlaba 1970) and Hungary (Igmándy 1970).

In southern Europe, $P$. pomaceus has been reported from France (Marchand 1976), Portugal (Pinto-Lopes 1949, Farinha 1956), Spain (Malencon \& Bertault 1971), Italy (Govi 1968), Greece (Crete: coll. Bickerich 15062, S, and 1977 Niemelä 545, H), Malta and Cyprus (Pegler \& Waterson 1968), Romania (Bontea 1953, Toma \& Pascal 1971), Bulgaria (Pilát 1936-1942), Yugoslavia (Tortić 1964) and European Turkey (Lohwag 1963).

The distribution in the Soviet Union includes Estonia (Parmasto 1956), Lithuania (Gričyus 1966), Latvia (Pilát 1936-1942), Byelorussia (Komarova 1964), the Bryansk region south of Moscow (Bondarcev 1912), the southern central Urals (Sverdlovsk: Stepanova-Kartavenko 1967), Armenia (Me-
lik-Hačatryan \& Martirosyan 1971), Kazakhstan (Sinadskij \& Bondarceva 1960, Švarcman 1964), and the Primorye and Khabarovsk territories and the Amur and Sakhalin regions in the Soviet Far East (Lyubarskij \& Vasilyeva 1975), though it is not mentioned from Kamchatka by Parmasto (1963). However, the picture of the distribution of $P$. pomaceus in the U.S.S.R. is rather sketchy. For instance, the northern distribution limit on the European side is not well documented.

On the whole, the Asian distribution is poorly known. P. pomaceus is common in Turkey (Pilát 1932, 1936-1942, Kotlaba 1976, Niemelä \& Uotila 1977). Saber (1972), Soleimani (1976) and Ershad (1977) report it from Iran. Kreisel (1961) includes 'Klein-, Mittel- und Ostasien' in the area of distribution, without giving any details. Pilát (19361942) mentions the species from China, and there is a specimen from the interior of China in Stockholm (coll. Gerardi, S). P. pomaceus has not been found in India, according to Bakshi (1971), Butler \& Bisby (1960) and Sarbhoy et al. (1975). In Japan, again, it is common (Imazeki \& Hongo 1971), but it is uncertain whether this distributional area joins the European one without interruption.

From Africa records exist from the north-western islands, e.g. Madeira (Lloyd 1915; coll. 1974 Väisälä 501, H) and the Canary Islands (Ryvarden 1972a). The species also occurs in continental North Africa (Kreisel 1961, Pilát 1936-1942), e.g. in Morocco, Algeria and Tunisia (G. Malencon, personal communication 1976, reviewing observations of Patouillard, Maire \& Werner and Malenøon \& Delecluse). Evidently it does not occur south of the Sahara, for instance in Angola (Pinto-Lopes 1966), Mozambique (Pinto-Lopes 1964) or East Africa (Ryvarden 1972b; though mentioned by Otieno 1968).

In North America, according to Neuman (1914), Shope (1931), Baxter (1952), Overholts (1953), Preston \& Dosdall (1955) and Gilbertson et al. (1974), the northern distribution limit runs through Maine, Ontario, Michigan, Minnesota, North Dakota and Montana. The species extends south to Georgia, Alabama, Missouri, Kansas, New Mexico, Colorado and Wyoming. It does not reach the west coast, according to these authors, or Alaska (Cash 1953). I have, however, seen a collection from British Columbia (coll. Kujala 68, HFR). Lowe (1957) and Guzmán \& Herrera (1971) report the species from Mexico.

P. pomaceus is not indigenous in South America. The record of Rick (1960) from Brazil has not been confirmed. However, according to Prof. Jorge E. Wright (personal communication 1976) it is now 
quite common in some areas of Argentina, where it has been introduced, and is spreading in connection with the cultivation of exotic fruit trees.

According to Cunningham (1965), who also corrects some wrong reports made by Lloyd (1915), $P$. pomaceus does not seem to occur in the Australian region.

The records of this species in Europe, Africa and SW Asia clearly show that it is more southern than $P$. igniarius. While $P$. igniarius is distributed in North Europe up to the subarctic (Niemelä 1975), $P$. pomaceus is restricted to the southern parts of Fennoscandia with mild winters, high summer temperatures and a longer growing season. In the Mediterranean countries, $P$. igniarius is rare and prefers higher altitudes, whereas $P$. pomaceus is frequently reported from the Mediterranean, including the African and Asian parts and the islands. Similarly, $P$. pomaceus has a more southern distribution in North America.

\section{Cultural characters}

Ten strains of $P$. pomaceus were studied, all except two derived from Finnish collections:

Finland:

Varsinais-Suomi, Karjalohja, Prunus cerasus, 1976 Aalto 537

- » - , Kemiö, $P$. cerasus, 1976 Niemelä 543

- » - , Korppoo, $P$. domestica, 1972 Niemelä 446

- ") - , Nauvo, P. domestica, 1972 Niemelä 449

Uusimaa, Inkoo, $P$. cerasus, 1975 Niemelä 527

- » - , Porvoo, P. domestica, 1976 Issakainen 538

- ) - , Tammisaari, P. insititia, 1967 Ákerman 236 (HFR)

Etelä-Karjala, Virolahti, P. domestica, 1967 Saarnijoki 161 (HFR)

Portugal:

Madeira, Funchal Monte, Prunus sp., 1974 Väisälä 501

Greece:

Crete, Nomós Lasithíou, Agios Nikólaos, Prunus sp., 1977 Niemelä 545

At $24^{\circ} \mathrm{C}$, the cultures grow rather rapidly. The radial growth is (14-) $18-21 \mathrm{~mm}$ in one week. At this age, the mycelium is thick and cottony, forming a dense cover over the inoculum. It is completely white, or with a diffuse ochre colouration at the centre, azonate but thinning gradually towards the margin.

After two weeks (Fig. 3), the mycelium has grown (30-) $35-43 \mathrm{~mm}$ and forms an even, thick, cottony mat with no distinct zonation. It is light ochre at the centre and white at the margin, the transition between these colours being very gradual. The white margin is narrow $(5-10 \mathrm{~mm})$ in some strains, and broader (up to $20 \mathrm{~mm}$ ) in others, but the variation between the strains is generally small.

At $24^{\circ} \mathrm{C}$, the $9-\mathrm{cm}$ Petri dishes with side inoculations are covered with mycelium in 3-4 weeks.

At $27-28^{\circ} \mathrm{C}$, radial growth is $17-23 \mathrm{~cm}$ in one week, (36-) 43-47 $\mathrm{mm}$ in two, and the Petri dishes become filled in $3(-4)$ weeks. At this temperature the mycelium is very similar to that at $24^{\circ} \mathrm{C}$ in both structure and colouration. After one week the mycelial mat is mostly white, with a cream or light ochre centre in some strains. After two weeks the central area is light ochre in all the strains.

The fully grown culture mat undergoes few changes with age. The one-month-old mat is thick and cottony, uniform in thickness and cinnamon to light ochre in colour. The hyphal tips tend to climb up the dish edges, but do not form the nodulous structures familiar in some other species of Phellinus with cottony mycelium. No pores are formed.

The advancing zone is formed of hyaline generative hyphae $2-3 \mu \mathrm{m}$ thick, with a few simple septa and branches.

The fully grown aerial mycelium is formed of a few generative hyphae $1.0-1.9 \mu \mathrm{m}$ thick, with 0.1 $\mu \mathrm{m}$ thick hyaline walls, simple septa and occasional branches. The skeletal hyphae are dominant, 1.5$3.0 \mu \mathrm{m}$ thick, with $0.2-0.8 \mu \mathrm{m}$ thick, light yellowish brown walls. The skeletals are flexuose, very seldom branched, aseptate or with a few secondary septa, sometimes with small lens-shaped swellings and hyphal coils. No setae, crustose structures, basidia or basidioles were found in any of the strains studied.

Sometimes in old mycelium patches of white bloom form near the edges of the Petri dishes. These contain only generative hyphae.

The cultures give a positive Bavendamm reaction on gallic acid agar medium.

Species code:

2. 6. 8. 26. 32. 38. 39. $43-44.54$.

The species code obtained from the European material agrees rather well with that of Nobles (1965), based on strains from North America. The only notable differences are the lack of fruiting areas (code n. 48), which are reported by Nobles (1965) and also by Campbell (1938) from the $\mathrm{N}$ American cultures, and the less distinct odour in the European strains.

Comparison with the species of the $P$. igniarius complex shows that the cultures of $P$. pomaceus resemble most closely $P$. laevigatus (Niemelä 1972) and the Cottony type of $P$. igniarius (Niemelä 1975). $P$. pomaceus differs from them in its somewhat 
slower growth, and in having much thicker mycelium, both at the margin and above the inoculum.

The staining, slow-growing mycelial variant (the Staining type), which has been found in $P$. tremulae (Niemelä 1977) and $P$. populicola (Niemelä 1975), was not found in $P$. pomaceus.

The two South European strains agreed well with the other cultures studied. The small overall variation between the strains used in this study reflects the homogeneity of the species. However, no cultures were obtained from Cornus, Crataegus or Olea.

\section{Pathology}

According to the herbarium labels of the ca. 470 Fennoscandian specimens investigated, the host trees were as follows:

\author{
Prunus domestica L. (incl. P. insititia L.) \\ $P$. cerasus $\mathrm{L}$. \\ $P$. spinosa L. \\ $P$. cerasifera Ehrh. (incl. $P$. divaricata Ledeb. \\ and $P$. pissardii Carr.) \\ $P$. avium L. \\ $P$. padus $\mathrm{L}$. \\ $P$. brigantina $\mathrm{L}$. \\ $P$. pennsylvanica $\mathrm{L}$. \\ $P$. triloba Lindl. \\ Prunus sp.
}

$\%$ of the specimens

43.5

22.5

12.2

Malus domestica Borkh. and M. sylvestris Mill.

Pyrus communis L.

Rhamnus catharticus L.

Sambucus sp.

Host not specified

As can be seen above, a great majority (over 90 $\%$ ) of the specimens have been collected from species of Prunus (in the wide sense of Tutin et al. 1968). In fact the percentage was probably even higher, as the greater part of the undocumented hosts presumably belonged to this genus. The numbers of specimens collected closely follow the frequency of the different species of Prunus within the region investigated. The only remarkable exception is Prunus padus, which is very common everywhere in Fennoscandia and on which $P$. pomaceus scarcely occurs at all.

To summarize, in Fennoscandia $P$. pomaceus occurs almost exclusively on Prunus subg. Prunus $(P$. brigantina, $P$. cerasifera, $P$. domestica, $P$. spinosa) and subg. Cerasus ( $P$. avium, $P$. cerasus, $P$. pennsylvanica), but only seldom on subg. Padus
(P. padus, $P$. triloba). In south Europe, Prunus subg. Amygdalus ( $P$. dulcis, $P$. persica) forms an important group of hosts to $P$. pomaceus.

Though interesting, the other host genera do not play an important role in the total occurrence of $P$. pomaceus in North Europe. Besides, as these records are based on only a few collections, the risk of host misidentification must be taken into consideration.

The simple host spectrum of $P$. pomaceus in Fennoscandia gives no clues to the identity of the fungi found on other hosts than Prunus and referred to this species. Such records have been listed by Donk (1974: 245-247). The most interesting of these are the collections from Cornus (Polyporus corni Velen., see Niemelä 1975), Crataegus (Fomes pomaceus f. crataegi Baxter, see Taxonomy) and Olea (see Marchand 1976).

$P$. pomaceus often occurs on the trunks of weakened, still living trees, and is a wound parasite that kills old plum and cherry trees. Most fruit bodies can be found on dead, still standing trees in uncared for, densely growing orchards and thickets. It does not normally cause much harm in intensive fruit cultivation, as the decay proceeds rather slowly, being extensive only in over-aged trees. The situation is roughly the same in Sweden (Dr. Ingvar Nordin, pers. comm.) as in Finland. However, the species seems to be much more harmful in central and south Europe (Jahn 1963, Marchand 1976).

The rot begins as a heartrot in living trees, but extends to the sapwood after the death of the host. The decay is of the delignifying type (white rot), finally becoming soft and light-weight, with chestnut brown zones. The brownish colour of the decay (more distinct in the N American material) is the reason for the many wrong reports that the fungus is a species causing brown rot (cellulosedecomposing; e.g. Shope 1931). As shown by Fisher (1935), the progress of decay, and susceptibility to the fungus vary to some extent in the different cultivars of the plum tree.

Acknowledgements. My sincere thanks are due to Dr. John Eriksson (Göteborg), Dr. Ingvar Nordin (Göteborg) and Dr. Ake Strid (Stockholm) for letting me investigate their private collections; to Dr. G. Malençon (Valognes) for information on the occurrence of $P$. pomaceus in $\mathrm{N}$ Afri$\mathrm{ca}$, and to Dr. Jorge E. Wright (Buenos Aires) for notes on the species in Argentina. I gratefully acknowledge the help of the staff of the herbaria from which loans were received.

Mrs. Anna A. Damström, M.A., revised the English of this paper. 


\section{References}

Ahti, T., Hämet-Ahti, L. \& Jalas, J. 1968: Vegetation zones and their sections in northwestern Europe. Ann. Bot. Fennici 5: 169-211.

Bakshi, B. 1971: Indian Polyporaceae. - 246 pp. New Delhi.

Balaban, K. \& Kotlaba, F. 1970: Atlas dřevokazných hub. - 135 pp. Praha.

Baxter, D. 1925: The biology and pathology of some of the hardwood heart-rotting fungi 2. - Am. J. Bot. 12: $553-576$.

- ) -1934: Some resupinate polypores from the region of the Great Lakes 5. - Papers Michigan Acad. Sci. Arts Lett. 19: 305-332.

- $)-1952$ : Some resupinate polypores from the region of the Great Lakes 23. - Papers Michigan Acad. Sci. Arts Lett. 37: 93-110.

Boerema, G. \& Verhoeven, A. 1972: Check list for scientific names of common parasitic fungi la. Fungi on trees and shrubs. - Netherl. J. Plant Pathol. 78 (suppl. 1): 1-63.

Bondarcev, A. 1912: Griby, sobrannye na stvolah lesnyh porod v Bryanskom opytnom Lesničestv. - Trudy po Lesnomu Opytnomu Delu v Rossii 37: $1-56$, pls. 14.

Bontea, V. 1953: Ciuperci parazitse i saprofite din Republica Popularā Românā. - 637 pp. Bucuresti.

Butler, E. \& Bisby, G. 1960: The fungi of India. - 552 pp. New Delhi.

Campbell, W. 1938: The cultural characteristics of the species of Fomes. - Bull. Torrey Bot. Club. 65: 3169.

Cash, E. 1953: A check list of Alaskan fungi. - Plant Dis. Rep. (Plant Dis. Surv. U.S. Dept. Agric.) Suppl. 219: $1-70$.

Cunningham, G. 1965: Polyporaceae of New Zealand. New Zealand Dept. Sci. Industr. Res. Bull. 164: 1304.

Domański, S., Orloś, H. \& Skirgiello, A. 1973: Fungi: Polyporaceae 2, Mucronoporaceae 2, Ganodermataceae, Bondarcewiaceae, Boletopsidaceae and Fistulinaceae. -332 pp. Warsaw.

Donk, M. 1971: Notes on European polypores 9. On some species of Hymenochaetaceae. - Proc. Koninkl. Nederl. Akad. Wetenschappen (C) 74: 405-421.

- »-1974: Check list of European polypores. - 469 pp. Amsterdam.

Ershad, D. 1977: Fungi of Iran. - Ministry Agric. Nat. Resourc., Plant Pests Dis. Res. Inst., Dept. Bot. Publ. 10: $1-277$.

Farinha, M. 1956: Contribuiçāo para o estudo das Polyporaceae de Portugal. - Portugaliae Acta Biol. (B) 5: 4-25.

Fisher, E. 1935: Observations on Fomes pomaceus (Pers.) Big. \& Guill. infecting plum trees. - Trans. Brit. Mycol. Soc. 19: 102-113.

Fries, E. 1836-1838: Epicrisis systematis mycologici... 610 pp. Upsaliae.

Gilbertson, R., Martin, K. \& Lindsey, J. 1974: Annotated check list and host index for Arizona wood-rotting fungi. - Univ. Arizona Agr. Exper. Sta. Techn. Bull. 209: 1 -48.

Göpfert, H. 1973: Notizen zur Verbreitung der hutbildenden Porlinge in der Schweiz. - Schweiz. Z. Pilzkunde 51: $17-31$.

Govi, G. 1968: Polyporaceae italiane 2. - Monti e Boschi 19(6): $31-44$.

Gray, S.F. 1821: A natural arrangement of British plants... 1. -824 pp., 21 pls. London.
Gričyus, A. 1966: Griby roda Phellinus v Litovskoj SSR. - Učenye Zapiski 74(2): 15-19.

Guzmán, G. \& Herrera, Y. 1971: Especies de macromicetos citadas de Mexico 2. Fistulinaceae, Meruliaceae y Polyporaceae. - Bol. Soc. Mexicana Micol. 5: 5777.

Hallgrimsson. H. 1966: Íslenskir sáldsveppir, Polyporaceae. - Ársrit Skógraektarfélags Islands 1966: 12-16.

Igmándy, Z. 1970: Die Porlinge Ungarns und ihre phytopathologische Bedeutung (Polypori Hungariae) 4. Acta Phytopathol. Acad. Sci. Hungaricae 5: 279-301.

Imazeki, R. \& Hongo, T. 1971: Coloured illustrations of fungi of Japan 1. - $181 \mathrm{pp}$. Osaka.

Jahn, H. 1963: Mitteleuropäische Porlinge (Polyporaceae s. lato) und ihr Vorkommen in Westfalen. - Westfälische Pilzbriefe 4: $1-143$.

Komarova, E. 1964: Opredelitel' trutovyh gribov Belorussii. $-343 \mathrm{pp}$. Minsk.

Kotlaba, F. 1976: Contribution to the knowledge of the Turkish macromycetes. - Ceská Mykol. 30: 156169.

Kreisel, H. 1961: Die phytopathogenen Grosspilze Deutschlands. -284 pp. Jena.

Lange, M. 1961: Illustreret svampeflora. - 242 pp. København.

Lloyd, C.G. 1915: Synopsis of the genus Fomes. - Mycol. Writings C.G. Lloyd 4: 209-288.

Lohwag, K. 1963: Mykologische Notizen aus dem Belgrader Wald bei Istanbul in der Türkei. - Sydowia, Ann. Mycol. 16 ('1962'): 199-204.

Lowe, J. 1957: Polyporaceae of North America. The genus Fomes. - State Univ. Coll. For. Syracuse Univ. Techn. Publ. 80: 1-97.

Lyubarskij, L. \& Vasil'yeva, L. 1975: Derevorazrušayušcie griby Dal'neko Vostoka. - 164 pp., 53 pls. Novosibirsk.

Malençon, G. \& Bertault, R. 1971: Champignons de la péninsule Ibérique. - Acta Phytotax. Barcinonensia 8: $1-94$

Marchand, A. 1976: Champignons du nord et du midi 4. Aphyllophorales (fin), Hydnaceae, Gasteromycetes, Ascomycetes. - 261 pp. Perpignan.

Melik-Hačatryan, D. \& Martirosyan, S. 1971: Mikoflora Armyanskoj SSR 2. Gasteromičety i afilloforovye griby. - 382 pp. Erevan.

Neuman, J. 1914: The Polyporaceae of Wisconsin. - Wisconsin Geol. Nat. Hist. Survey Bull. 33: $1-156$, pls. $1-25$.

Niemelä, T. 1972: On Fennoscandian polypores 2. Phellinus laevigatus (Fr.) Bourd. \& Galz. and P. lundellii Niemelä, n. sp. - Ann. Bot. Fennici 9: 41-59.

- \-1974: On Fennoscandian polypores 3. Phellinus tremulae (Bond.) Bond. \& Borisov. - Ann. Bot. Fennici 11: 202-215.

- ) -1975: On Fennoscandian polypores 4. Phellinus igniarius, $\mathrm{P}$. nigricans and $\mathrm{P}$. populicola, n. sp. - Ann. Bot. Fennici 12: 93-122.

- $)-1977$ : The effects of temperature on the two culture types of Phellinus tremulae (Fungi, Hymenochaetaceae). - Ann. Bot. Fennici 14: 21-24.

Niemelä, T. \& Uotila, P. 1977: Lignicolous macrofungi from Turkey and Iran. - Karstenia 17: 33-39.

Nobles, M. 1965: Identification of cultures of woodinhabiting Hymenomycetes. - Canad. J. Bot. 43: $1097-1139$.

Otieno, N. 1968: A check list of Polyporaceae of East and Central Africa. - Sydowia, Ann. Mycol. 22: 199215 . 
Overholts, M. 1953: The Polyporaceae of the United States, Alaska, and Canada. - $456 \mathrm{pp}$. Ann Arbor.

Palmgren, S. \& Lokonen, P. (eds.) 1969: Kaunis kotipiha. -112 pp. Helsinki.

Parmasto, E. 1956: Tähtsamate Eesti NSV torikuliste määraja. $-70 \mathrm{pp}$. Tartu.

- -1963: K flore gribov poluostrova Kamčatki. - Issl. Prirody Dal'nego Vostoka 1: 221-289.

Pegler, D. 1966: Polyporaceae 1. With a key to British genera. - Brit. Mycol. Soc. News Bull. 26: 14-28.

Pegler, D. \& Waterson, J. 1968: Phellinus pomaceus. C.M.I. Descr. Pathog. Fungi Bact. 196: 1-2.

Persoon, C.H. 1799: Observationes mycologicae 2. - 106 pp., 6 pls. Lipsiae \& Lucernae.

Pilát, A. 1932: Contribution à l'etude des Hyménomycètes de l'Asie Mineure, première partie. - Bull. Soc. Mycol. France 48: 162-189, pls. 14-22.

- 》-1936-1942: Polyporaceae 1-2. In: Kavina, C. \& Pilát, A. (eds.), Atlas des champignons de l'Europe 3. - 624 pp., 374 pls. Praha.

Pinto-Lopes, J. 1949: On the Polyporaceae of Portugal. Portug. Acta Biol. (B), vol. J. Henriques: 211-217.

- »-1964: Polyporaceae of Mozambique. - Bol. Soc. Portuguesa Ci enc. Nat. (2a) 10: 116-132.

- »-1966: Catalogue of Polyporaceae of Angola. - Bol. Soc. Portuguesa Ciênc. Nat. (2a) 11: 47-79.

Preston, D. \& Dosdall, L. 1955: Minnesota plant diseases. - Agr. Res. Serv. U.S. Dept. Agr. (Plant Dis. Epidem. Ident. Sect.), Special Publ. 8: 1-184.

Rick, J. 1960: Basidiomycetes Eubasidii in Rio Grande do Sul - Brasília 4. Meruliaceae, Polyporaceae, Boletaceae. - Iheringia, Sér. Bot. 7: 193-295.

Ryvarden, L. 1972a: Studies on the Aphyllophorales of the Canary Islands with a note on the genus Perenniporia Murr. - Norw. J. Bot. 19: 139-144.
Ryvarden, L. 1972b: A critical check list of the Polyporaceae in tropical East Africa. - Norw. J. Bot. 19: $229-238$.

Ryvarden, L. \& Calonge, F. 1976: Type studies in the Polyporaceae 5 . Species described by Lázaro E. Ibiza. - Nova Hedwigia 27: 155-164.

Saber, M. 1972: Identification of Homobasidiomycetes collected in Iran. - Iranian J. Plant Path. 8: 13-19.

Sarbhoy, A., Lal, G. \& Varshney, J. 1975: Fungi of India 1967-1971. - 149 pp. New Delhi.

Shope, P. 1931: The Polyporaceae of Colorado. - Ann. Missouri Bot. Garden 18: 287-456.

Sinadskij, J. \& Bondarceva, M. 1960: Nekotorye trutovye griby na listvennyh porodah $\mathrm{v}$ pojme reki Ural. Bot. Mater. Otdela Spor. Rast. Akad. Nauk SSSR 13: $222-232$.

Soleimani, P. 1976: Wood destroying fungi in Iran. Eur. J. Forest Pathol. 6: 75-79.

Stepanova-Kartavenko, N. 1967: Afilloforovye griby Urala. -295 pp. Sverdlovsk.

Švarcman, S. 1964: Geterobazidial'nye i avtobazidial'nye griby. In: Flora sporovyh rastenij Kazahstana 4. - 715 pp. Alma-Ata.

Toma, M. \& Pascal, P. 1971: Macromicete din bazinul Bistritei Aurii, jud. Suceava. - Stud. Comunicāri Muz. Stiinţele Nat. Bacāu 1971: 641-645.

Tortić, M. 1964: Prilog poznavanju viših gljiva okolice Zagreba. - Acta Bot. Croatica 23: 73-100.

Tutin, T., Heywood, V., Burges, N., Moore, D., Valentine, D., Walters, S. \& Webb, D. (eds.) 1968: Flora Europaea 2, Rosaceae to Umbelliferae. - $455 \mathrm{pp}$. Cambridge.

Ullström, K.-E. (ed.) 1961 : Sveriges pomologiska förenings växtatlas. - $103 \mathrm{pp}$. Kristianstad. 